\title{
Sorption of Phenobarbital and Amobarbital on Na-montmorillonite
}

\author{
MIRCEA STEFAN ${ }^{1,2}$, DANIELA - SIMINA STEFAN ${ }^{1 *}$, MADALINA HRUBARU ${ }^{3}$, \\ CICERONE MARINESCU ${ }^{4}$, IOANA STEFAN ${ }^{5}$ \\ ${ }^{1}$ University Politehnica from Bucharest, Faculty of Applied Chemistry and Materials Science, 1-7 Polizu Str., \\ 011061, Bucharest, Romania \\ ${ }^{2}$ University Titu Maiorescu, Pharmacy Faculty, 22 Dambovnicului Str., 040441, Bucharest, Romania \\ ${ }^{3}$ Center of Organic Chemistry C.D. Nenitescu, Bucharest, 202B Splaiul Independentei, 060023, Bucharest, \\ Romania \\ ${ }^{4}$ University of Pitesti, 1 Tg. din Vale, 110040, Pitesti, Romania \\ ${ }^{5}$ University of Medicine and Pharmacy Carol Davila, Pharmacy Faculty, 37 Dionisie Lupu Str., 020021, \\ Bucharest, Romania
}

\begin{abstract}
In order to characterize the sorption kinetics of phenobarbital sodium and amobarbital sodium on natural $\mathrm{Na}$ - montmorillonite, the influence of the initial drug concentration and clay particles sizes was investigated. Equilibrium isotherms have been measured and analyzed using a Langmuir isotherm model. The affinity of drugs sorbed onto clay varied in the following descending order: phenobarbital sodium > amobarbital sodium, respectively 11.2 and $9.1 \mathrm{mg} / \mathrm{g}$. Also, sorption of phenobarbital sodium and amobarbital sodium on Na-montmorillonite was studied as a function of $\mathrm{pH}$. The results show that adsorption of the drugs is highest below the $\mathrm{pH}_{Z P C}$ due the neutrality of the drugs which adsorbs via an attraction of the positively charged surface sites at lower $\mathrm{pH}$ by weak van der Waals forces.
\end{abstract}

Keywords: phenobarbital, amobarbital, sorption, montmorillonite, HPLC

\section{Introduction}

Activated carbon and bentonite-montmorillonite are ones of the most commonly used natural products in emergency situations especially as a household remedy.

Smectites are widespread minerals of weathering formation and sediment [1] that possess a large specific surface area and a high structural charge (up to $1000 \mathrm{meq} / \mathrm{kg}$ ) [2].

The lamellar and defective structure of smectites determines a high surface reactivity of this mineral. The most common smectite is montmorillinite, with a general chemical formula $(1 / 2 \mathrm{Ca}, \mathrm{Na})(\mathrm{Al}, \mathrm{Mg}, \mathrm{Fe})_{4}$ $(\mathrm{Si}, \mathrm{Al})_{8} \mathrm{O}_{20}(\mathrm{OH})_{4} \cdot \mathrm{nH}_{2} \mathrm{O}$. Montmorillinite is the main constituent of bentonite, derived by weathering of volcanic ash. Montmorillinite can expand by several times its original volume when it comes in contact with water [3].

The structure of montmorillonite consists in layers made by the condensation of one central octahedral sheet and two tetrahedral sheets. Montmorillonite is characterized by metal ion substitutions within his lattice structures, so that it is electrically unbalanced.

Montmorillonite is characterized by the substitution of a limited number of octahedral $\mathrm{Al}^{3+}$ with $\mathrm{Mg}^{2+}$ that accounts for its negative charge which is compensated by the sorption of cations on basal planes. These cations form outer-sphere (OS) surface complexes $[4,5]$ and are easily exchanged with solute ions by varying the cationic composition of the solution. Besides these cation exchange properties, the montmorillonite also possesses $\mathrm{pH}$ dependent sorption properties [3].

*email: simina_stefan_ro@yahoo.com 
Physical and physiochemical properties of clay minerals like kaolin, smectite and palygorskite-sepiolite have led them to be used in pharmaceutical preparations as either active ingredients (having therapeutic properties), or excipients.

The research studies about minerals used in pharmaceutical industry show that the main properties of clay minerals which make them to be used in pharmaceuticals are their high adsorption capacity, high specific area, chemical inertness, favorable rheological properties, swelling capacity, as well as thixotropic and colloidal properties besides being non-toxic to humans.[6-10].

Phenobarbital sodium (5-ethyl-4,6-dioxo-5-phenyl-1H-pyrimidin-2-olate sodium) is a barbituric acid derivative that acts as a nonselective central nervous system depressant. It binds to gammaaminobutyric acid A (GABAA)-sensitive ion channels found in the central nervous system, where they allow an influx of chloride into cell membranes and, subsequently, hyperpolarize the postsynaptic neurons [11]. The drug is a first-line agent of choice for treatment of neonatal seizures [12].

Toxic effects of overexposure may include prolonged coma, cardiovascular depression with hypotension and shock leading to renal failure, hypothermia and pyrexia. Death may occur due to respiratory and circulatory failure [13].

Amobarbital (formerly known as amylobarbitone or amytal sodium) chemically designated as 5ethyl-5-(3-methylbutyl)-4,6-dioxo-1H-pyrimidin-2-olate sodium is a drug that is a barbiturate derivative. Amobarbital works by depressing the brain's sensory cortex, which decreases motor activity and changes cerebellar function, resulting in drowsiness, sedation and hypnosis. If amobarbital is taken for extended periods of time, physical and psychological dependence can develop.

An overdose on amobarbital can vary in severity but often includes the following symptoms: depression of the central nervous system, irregular breathing, decreased urine output, irregular heartbeat, hypotension, coma, shock, hypothermia, ceased electrical activity in brain. [11].

Therefore, we have investigated Na-montmorillonite as an antidote for phenobarbital and amobarbital overdose.

\section{Materials and methods}

The montmorillonite used in this study was a natural Na-montmorillonite supplied by I.C.P.M MINESA - S.A. Cluj Napoca.

Mineral clay has $99 \%$ of the clay particles $<10 \mu \mathrm{m}$ and a cation exchange capacity (CEC) of about $0.92 \mathrm{meq} / \mathrm{g}$. The drugs used in the present work were phenobarbital sodium and amobarbital sodium. Information regarding the two drugs are presented in Table 1.

Table 1

Information on the drugs molecules

\begin{tabular}{|c|c|c|c|}
\hline Product & Formula & Molar mass $\left(\mathrm{g} \mathrm{mol}^{-1}\right)$ & Supplier \\
\hline $\begin{array}{c}\text { Amobarbital } \\
\text { sodium }\end{array}$ & $\mathrm{C}_{11} \mathrm{H}_{17} \mathrm{~N}_{2} \mathrm{NaO}_{3}$ & 248.26 & $\begin{array}{c}\text { Valeant Pharmaceutical } \\
\text { North America LLC }\end{array}$ \\
\hline $\begin{array}{c}\text { Phenobarbital } \\
\text { sodium }\end{array}$ & $\mathrm{C}_{12} \mathrm{H}_{11} \mathrm{~N}_{2} \mathrm{NaO}_{3}$ & 254.221 & Zentiva Romania \\
\hline
\end{tabular}

The stock phenobarbital sodium and amobarbital sodium solutions was prepared by dissolving the adsorbate in $500 \mathrm{~mL}$ of simulated intestinal fluid.

\section{Clay characterization methods}

In order to analyze the chemical composition of mineral clay X-ray fluorescence (XRF) technique was used. XRF were performed using a JASCO FP-6500 Analyser.

A Shimadzu XRD 6000 diffractometer with Ni filtered $\mathrm{Cu} \mathrm{K \alpha}$ radiation $(\lambda=1.5406 \AA)$ was used in order to determine X-ray diffraction (XRD) pattern of natural Na-montmorillonite. 
A Perkin-Elmer Spectrum 100 spectrometer with ATR was used to perform investigation of clay samples by the FTIR method. Bands were recorded as the absorbance function, within the wave number range $4000-400 \mathrm{~cm}^{-1}$.

Scanning electron microscopy images (SEM) were obtained using a HITACHI S2600N. Surface area, pore volume, pore size distribution were determined by us in previous study [14-16] using standard $\mathrm{N}_{2}$ adsorption techniques [17]. Total pore volume was calculated from amount of adsorbed $\mathrm{N}_{2}$ at P/Po 0.95. [18]. The micropore volume was determined by Dubinin-Radushkevich method [19]. Mesopore volume was calculated from the amount of $\mathrm{N}_{2}$ adsorbed between relative pressures P/Po 0.40-0.95. We considered $35.0 \mathrm{~cm}^{3} / \mathrm{mol}$ the molar volume of liquid nitrogen [20].

$p \mathrm{H}$ at zero point of change (pHzpc) was calculated using $\mathrm{pH}$-drift method [21]. The $\mathrm{pHzpc}$ was determined as the point where the curve $p \mathrm{H}$ final $v s p \mathrm{H}$ initial intersects the line $p \mathrm{H}$ initial $=p \mathrm{H}$ final [21].

\section{Simulated intestinal fluid preparation}

Simulated intestinal fluid (SIF) without pancreatin was prepared according to the United States Pharmacopeea, [22]. Monopotasic $\mathrm{KH}_{2} \mathrm{PO}_{4}(6.8 \mathrm{~g})$ was dissolved into $50 \mathrm{~mL}$ of water. To this $190.0 \mathrm{~mL}$ of $0.2 \mathrm{~N} \mathrm{NaOH}$ and water were added to make $1000 \mathrm{~mL}$ ( $p \mathrm{H}$ adjusted to $7.0 \pm 0.1$ with $0.2 \mathrm{~N} \mathrm{NaOH}$ ).

\section{Sorption kinetic of phenobarbital sodium and amobarbital sodium Sorption for different initial drug concentrations}

Sorption experiments were carried out for three different initial concentrations of drugs (approximately 6,12 , and $18 \mathrm{~g} / \mathrm{L}$ ) at $37.0 \pm 0.1^{\circ} \mathrm{C}$ in glass vessels immersed in a thermostatic water bath.

Three grams of Na- montmorillonite were contacted with $15 \mathrm{~mL}$ of phenobarbital and amobarbital, respectively, SIF solutions.

The suspensions $p \mathrm{H}$ was maintained at $6.8 \pm 0.05$ by adding small volumes of $10^{-2} \mathrm{M} \mathrm{NaOH}$ or $10^{-2}$ $\mathrm{M} \mathrm{HNO}_{3}$ solutions. The $p \mathrm{H}$ was monitored by a $p \mathrm{H}$ electrode connected to a $\mathrm{pH}$ meter (Agilent 3200P). The electrode was calibrated with buffers (Merk, titrisol) at $20^{\circ} \mathrm{C}$.

A vigorous stirring of the suspension was ensured by a rotating magnetic bar.

At given times, 5-mL samples were withdrawn from the reaction vessel and immediately centrifuged.

The phenobarbital sodium and amobarbital sodium concentrations, both before the addition of Namontmorillonite and after contacting with this mineral clay, were determined with a high-performance liquid chromatography (HPLC) system. The HPLC system included the following equipment: liquid pump Model LC-10AS, integrator Model CR501, variable wavelength UV-VIS detector Model SPD10A, auto-injector Model SIL-10A, and system controller Model SCL-10A (all from Shimadzu Scientific Instruments).

The amount of adsorbed drug was calculated by means of the difference between the initial and the final solution concentration.

\section{Sorption on different Na-montmorillonite particle sizes}

Sorption studies were carried out similarly as described before but for three different particle sizes respectively $<2 \mu \mathrm{m},(4-6) \mu \mathrm{m}$ and (8-10) $\mu \mathrm{m}$. The initial concentration of drugs in suspension was approximately $18 \mathrm{mg} / \mathrm{mL}$.

\section{Effect of $p H$ on phenobarbital sodium and amobarbital sodium sorption}

Three grams of natural Na- montmorillonite were contacted for $2 \mathrm{~h}$ (till equilibrium attainment) with $15 \mathrm{~mL}$ of phenobarbital and amobarbital SIF solutions with drug initial concentrations of $18 \mathrm{mg} / \mathrm{mL}$. The experiments were performed at $37.0 \pm 0.1^{\circ} \mathrm{C}$ in glass vessels immersed in a thermostatic water bath. The $p \mathrm{H}$ was varied from about 6 to 9.5 and adjusted by adding small volumes of $10^{-2} \mathrm{M} \mathrm{NaOH}$ or 
$10^{-2} \mathrm{M} \mathrm{HNO}_{3}$ solutions. A $p \mathrm{H}$ electrode connected to a $\mathrm{pH}$ meter (Agilent 3200P) was used for $p \mathrm{H}$ measuring. This electrode was calibrated with buffers (Merk, titrisol) at $20^{\circ} \mathrm{C}$.

A vigorous stirring of the suspension was ensured by a rotating magnetic bar.

After equilibration, clays and solutions were separated by centrifugation (Universal $32 \mathrm{Hettich)}$ at $10000 \mathrm{rpm}$ for $30 \mathrm{~min}$.

\section{Sorption equilibrium of phenobarbital sodium and amobarbital sodium}

Three grams of Na- montmorillonite were contacted for $2 \mathrm{~h}$ with $15 \mathrm{~mL}$ of phenobarbital and amobarbital SIF solutions with drug concentrations ranging from 2 to $20 \mathrm{mg} / \mathrm{mL}$.

The $p \mathrm{H}$ of the drug solutions was $6.8 \pm 0.05$. Isotherms for drugs sorption on $\mathrm{Na}$ - montmorillonite were determined at $37 \pm 0.1^{\circ} \mathrm{C}$ in glass vessels immersed in a thermostatic water bath.

After equilibrium attainment, clays and solutions were separated by centrifugation (Universal 32 Hettich) at $10000 \mathrm{rpm}$ for $30 \mathrm{~min}$.

The concentrations of phenobarbital sodium and amobarbital sodium in the supernatant were determined with the HPLC system described before. The amounts of adsorbed drugs were calculated as the difference between initial and final solutions concentrations.

All measurements were run in duplicate. The reported values represent the average values.

\section{Results and discussions \\ Characterization of the raw clay XRF characterization}

The chemical composition of the minerals present in the clay have been studied. The data presented in Table 2 show that the clay is composed of silica, aluminum, sodium, iron, potassium and calcium oxides in major quantities and other elements in trace amounts.

Table 2. Chemical analysis of smectite clay

\begin{tabular}{|c|c|c|c|c|c|c|c|c|}
\hline $\begin{array}{c}\text { Chemical } \\
\text { composition }\end{array}$ & $\mathrm{SiO}_{2}$ & $\mathrm{Al}_{2} \mathrm{O}_{3}$ & $\mathrm{Fe}_{2} \mathrm{O}_{3}$ & $\mathrm{~K}_{2} \mathrm{O}$ & $\mathrm{CaO}$ & $\mathrm{TiO}_{2}$ & $\mathrm{ZrO}_{2}$ & $\mathrm{Na}_{2} \mathrm{O}$ \\
\hline $\begin{array}{c}\text { Raw clay } \\
\text { weight \% }\end{array}$ & 71.3 & 13.4 & 3.37 & 1.97 & 1.94 & 0.607 & 0.083 & 7.33 \\
\hline
\end{tabular}

\section{FTIR characterization}

In order to investigate the surface characteristics of bentonite vibrational spectrum was investigated using FTIR spectroscopy technique. The Na-montmorillonite spectrum obtained by the FTIR technique is presented in Figure 1.

Vibrations of $\mathrm{OH}$ groups (present in $\mathrm{Al}-\mathrm{OH}-\mathrm{Al}$, and $\mathrm{Fe}-\mathrm{OH}-\mathrm{Al}$ ) exhibit the maximum at the wave number of approximatively $3409 \mathrm{~cm}^{-1}$. The band that arises at $1632 \mathrm{~cm}^{-1}$ in the spectrum of clay suggests the presence of bending $\mathrm{H}-\mathrm{O}-\mathrm{H}$ vibration. The band corresponding to Al-Al-OH is observed at $899 \mathrm{~cm}^{-}$ ${ }^{1}$. The bending mode of $\mathrm{Si}-\mathrm{O}$ is strongly evident in the silicate structure, showing absorption bands at 1013,1116 , and $773 \mathrm{~cm}^{-1}$ arising from the stretching and bending vibrations of $\mathrm{SiO}_{2}$ tetrahedral [23]. Si$\mathrm{O}$ stretching vibrations observed at $773 \mathrm{~cm}^{-1}$ supports the presence of quartz. The presence of calcium combined with carbonate species reveals the existence of calcite as confirmed by FTIR at 1428 . 


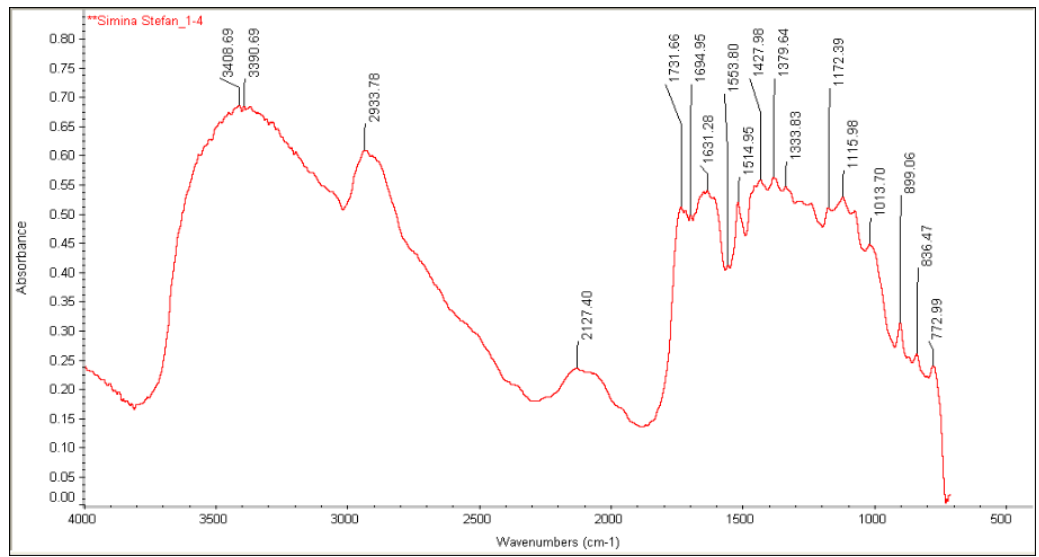

\section{Figure 1.}

Na-monmorillonite spectrum obtained by the infrared spectroscopy method

\section{$X$-ray diffraction characterization}

$\mathrm{X}$-ray diffraction (XRD) was applied in order to define the mineralogical composition of the raw clay. The composition of clay was identified by comparing " $d$ " values. Results indicate the presence of montmorillonite $(12.3 \AA)$, kaolinite $(7.24 \AA)$, calcite $(3.05 \AA)$ and quartz (3.31 $\AA$ ) and the sodium character of this clay.

\section{SEM analysis}

The scanning electron microscope (SEM) is suited for studying clays because it affords a magnified, three-dimensional view of the unmodified (natural) clay surface with great depth of focus. Figure 2 presents SEM micrographs of raw clay and indicates the presence of diverse size particles with a diameter of the range of $1.5 \mu \mathrm{m}$.

SEM examination of the studied sample showed the predominance of the clay mineral montmorillonite, which was verified by XRD. A Na-montmorillonite is more open-textured or fluffy, presumably because the $\mathrm{Na}^{+}$interlayer ion is more easily hydrated.

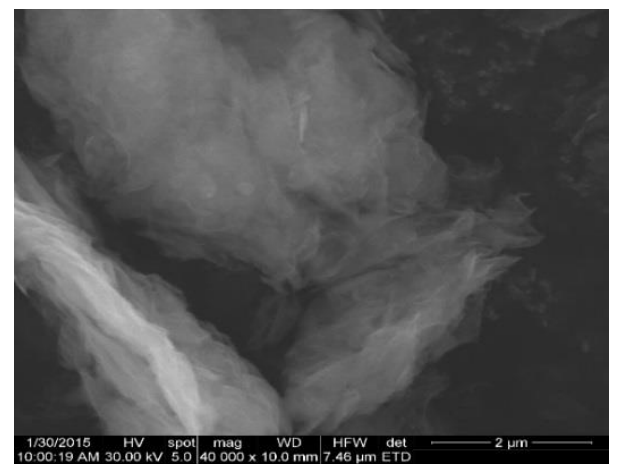

Figure 2. SEM

micrographs of natural

Na-montmorillonite

\section{Specific surface area and pore size distribution}

Specific surface area (SSA) of Na-montmorillonite was obtained by $\mathrm{N}_{2}$ adsorption at $77 \mathrm{~K}$. SSA was calculated by applying the BET method as $112.4 \mathrm{~m}^{2} \mathrm{~g}^{-1}$.

The textural characteristics of adsorbent including particle size distribution, pore diameters, pore volume, pore size distribution are presented in Table 3 and Table 4.

Table 3. Particle size distribution

\begin{tabular}{|c|c|}
\hline Fraction & $\%$ \\
\hline$<2 \mu \mathrm{m}$ & 92.1 \\
\hline $4-6 \mu \mathrm{m}$ & 3.9 \\
\hline $8-10 \mu \mathrm{m}$ & 4 \\
\hline
\end{tabular}


Table 4. Pore size distribution

\begin{tabular}{|c|c|c|c|}
\hline Pore diameter & Pore distribution, $\%$ & \multirow{7}{*}{ Pore volume $(0-300 \AA \hat{)}), \mathrm{cm}^{3} / \mathrm{g}$} & \multirow{7}{*}{0.153} \\
\hline $5-10 \AA ̊$ & 0 & & \\
\hline $10-15 \AA$ & 9.67 & & \\
\hline $15-25 \AA$ & 25.85 & & \\
\hline 25-50 ̊́ & 28.41 & & \\
\hline $50-100 \AA ̊$ & 10.81 & & \\
\hline $100-300 \AA ̊$ & 25.26 & & \\
\hline $300-1000 \AA$ & 0 & \multirow{3}{*}{ Pore volume (300-75000Á), $\mathrm{cm}^{3} / \mathrm{g}$} & \multirow{3}{*}{0} \\
\hline 1000-10000 Á & 0 & & \\
\hline $10000-75000 \AA ̊$ & 0 & & \\
\hline
\end{tabular}

\section{Effect of $p H$ on phenobarbital sodium and amobarbital sodium sorption}

The kinetic of phenobarbital sodium and amobarbital sodium uptake by Na-montmorillonite at different initial concentrations and for different clay particle sizes is illustrated in Figures 3-6.

The amount, $q_{t}$, of drugs sorbed at time $t$, is calculated from the mass balance equation:

$$
q_{t}=\left(C_{0}-C_{t}\right) V / M
$$

where:

$\mathrm{C}_{0}$ - initial metal concentration

$\mathrm{C}_{\mathrm{i}}$ - final metal concentration

$\mathrm{V}$ - volume of solution

$\mathrm{M}$ - mass of sorbent

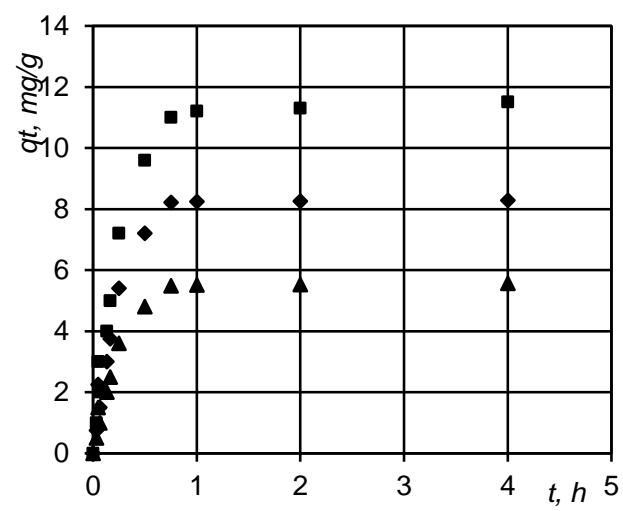

Figure 3. The dependence of phenobarbital sodium concentration in solid phase on the contact time sorption, for different initial concentrations $\mathrm{T}=37.0 \pm 0.1^{\circ}$

$\mathrm{C} ; p \mathrm{H}=6.80 \pm 0,05 ; \square \mathrm{C}_{\mathrm{i}}=18$ $\mathrm{mg} / \mathrm{mL} ; \mathrm{C}_{\mathrm{i}}=12 \mathrm{mg} / \mathrm{mL}$; $\Delta \mathrm{C}_{\mathrm{i}}=6 \mathrm{mg} / \mathrm{mL}$

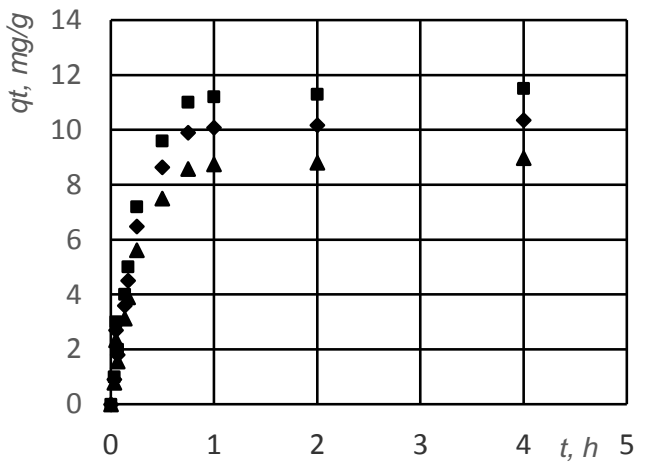

Figure 4. The dependence of phenobarbital sodium concentration in solid phase on the contact time sorption, for different clay particle size $\mathrm{T}=37.0 \pm 0.1^{\circ} \mathrm{C} ; p \mathrm{H}=6.80 \pm 0,05$; $\mathrm{C}_{\mathrm{i}}=18 \mathrm{mg} / \mathrm{mL} ; \boldsymbol{D}<2 \mu \mathrm{m} ;$ $\mu \mathrm{m}<\mathrm{D}<6 \mu \mathrm{m} ; \boldsymbol{\Delta} 8 \mu \mathrm{m}<\mathrm{D}<10$ 


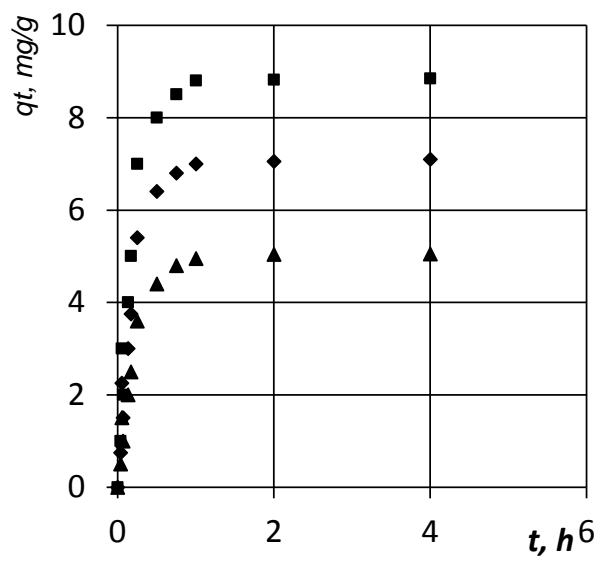

Figure 5. The dependence of amobarbital sodium concentration in solid phase on the contact time sorption, for different initial concentrations $\mathrm{T}=37.0 \pm 0.1^{\circ} \mathrm{C} ; p \mathrm{H}=$ $6.80 \pm 0,05 ;-\mathrm{C}_{\mathrm{i}}=18 \mathrm{mg} / \mathrm{mL} ; \diamond \mathrm{C}_{\mathrm{i}}=12$ $\mathrm{mg} / \mathrm{mL} ; \boldsymbol{\Delta} \mathrm{C}_{\mathrm{i}}=6 \mathrm{mg} / \mathrm{mL}$

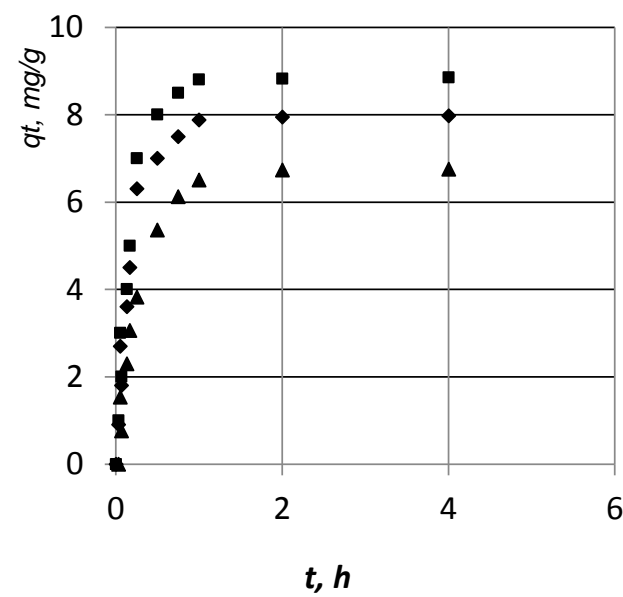

Figure 6. The dependence of amobarbital sodium concentration in solid phase on the contact time sorption, for different clay particle size $\mathrm{T}=37.0 \pm 0.1^{\circ} \mathrm{C} ; p \mathrm{H}=6.80 \pm 0,05 ; \mathrm{C}_{\mathrm{i}}=18$ $\mathrm{mg} / \mathrm{mL} ; \boldsymbol{D}<2 \mu \mathrm{m} ; \bullet 4 \mu \mathrm{m}<\mathrm{D}<6 \mu \mathrm{m}$; $\Delta 8 \mu \mathrm{m}<\mathrm{D}<10 \mu \mathrm{m}$

The influence of the initial concentration of phenobarbital sodium and amobarbital sodium on the sorption rate is shown in figures 3 and 5. Increasing of the initial drug concentration one obtain the increase of the amount of drug uptake.

For all three values of the initial concentrations the drugs adsorption equilibrium was reached within $2 \mathrm{~h}$ of shaking. The amounts of drugs adsorbed after $5 \mathrm{~h}$ were not significantly different from the amounts adsorbed after $2 \mathrm{~h}$. Therefore, $2 \mathrm{~h}$ were considered sufficient time to reach drug adsorption equilibrium.

The effect of the Na-montmorillonite particle size was investigated. As shown in figures 4 and 6 the sorption rate of drugs on mineral clay is dependent on montmorillonite particle size used. The amounts of phenobarbital sodium and amobarbital sodium on $\mathrm{Na}$-montmorillonite increases while the clay particle size decreases.

\section{Effect of $p H$ on phenobarbital sodium and amobarbital sodium sorption}

The adsorption of phenobarbital sodium and amobarbital sodium on the Na-montmorillonite is governed primarily by the $\mathrm{pH}$ of the bulk solution and the surface charge of the adsorbent. The $p \mathrm{H}$ dependent charge is located at the edge sites, where the surface hydroxyl groups can be protonated or deprotonated, depending on the $\mathrm{pH}$ of solution.

The $p \mathrm{H}_{\mathrm{ZPC}}$ of sodium montmorillonite was determined as 7.3. The surface of the adsorbents is positively charged below the $p \mathrm{H}_{\mathrm{ZPC}}$ and negative above the point. The results show that adsorption of both drugs is higher below this point (Figure 7) due the neutrality of the drug which adsorbs via an attraction of the positively charged surface sites at lower $p \mathrm{H}$ by weak van der Waals forces [24]. The decreases in adsorption above $p \mathrm{H}_{\mathrm{ZPC}}$ could be attributed to gradual ionization of phenobarbital sodium and amobarbital sodium in alkaline medium as a result of lactam-lactim tautomerism at higher $\mathrm{pH}$ which is as a result of active methylene group (upon tautomerization) 
between two carbonyl groups of phenobarbital or amobarbital and the presence of a diiminocarbonyl system in the tautomeric forms [25].

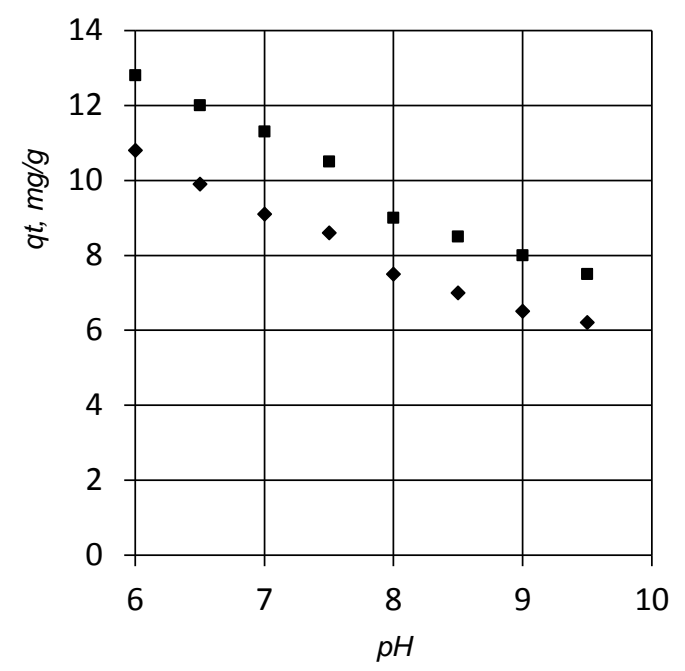

Figure 7. The dependence of drugs solid phase concentration on $p \mathrm{H}$ at equilibrium

$\mathrm{C}_{\mathrm{i}}=18 \mathrm{mg} / \mathrm{L} ; \mathrm{T}=37.0 \pm 0,1{ }^{\circ} \mathrm{C}$;

- phenobarbital sodium

$\checkmark$ amobarbital sodium

Removal of drugs from their SIF solutions by mineral clay was $p \mathrm{H}$ dependent. The minimum and maximum amounts of drugs adsorbed on Na- montmorillonite are presented in Table 5.

Table 5. The minimum and maximum amounts of drugs adsorbed on na- montmorillonite

\begin{tabular}{|c|c|c|}
\hline \multirow{2}{*}{ Drug } & $\mathrm{pH}$ & $\mathrm{qt}_{\mathrm{t}}(\mathrm{mg} / \mathrm{g})$ \\
\hline \multirow{2}{*}{$\begin{array}{c}\text { Amobarbital } \\
\text { sodium }\end{array}$} & 6.02 & 10.7 \\
\cline { 2 - 3 } & 9.49 & 6.2 \\
\hline $\begin{array}{c}\text { Phenobarbital } \\
\text { sodium }\end{array}$ & 6.01 & 12.8 \\
\cline { 2 - 3 } & 9.50 & 7.5 \\
\hline
\end{tabular}

Sorption equilibrium of phenobarbital sodium and amobarbital sodium

Phenobarbital sodium and amobarbital sodium adsorption isotherms are presented in Figure 8.

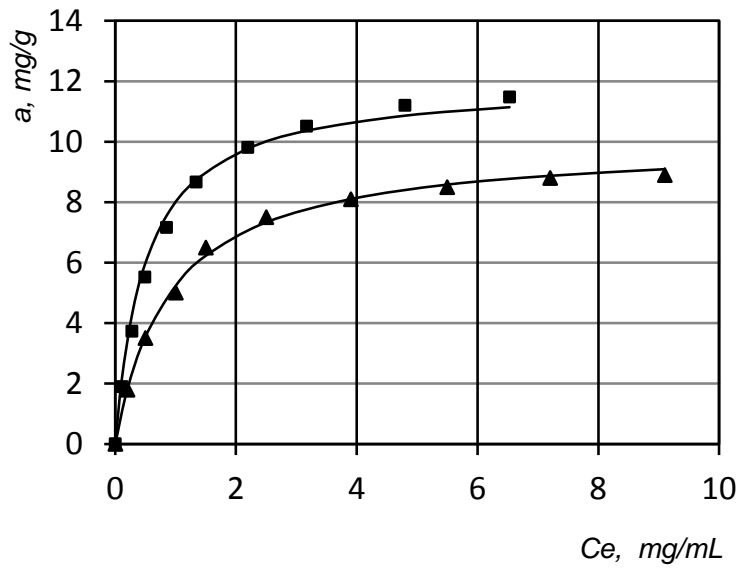

Figure 8. Phenobarbital sodium and Amobarbital sodium adsorption isotherms; Symbols are experimental data points, whereas lines are the Langmuir-fit adsorption curves. $p \mathrm{H}=6.80 \pm 0.05 ; \mathrm{T}=37.0 \pm 0,1{ }^{\circ} \mathrm{C}$;

- phenobarbital sodium amobarbital sodium

The drugs sorption data were well described by the Langmuir equation:

where:

$$
a=a_{m} \frac{b C}{1+b C}
$$


a - equilibrium concentration of adsorbed metal

$\mathrm{C}$ - equilibrium concentration of metal in solution

$\mathrm{a}_{\mathrm{m}}$ - the maximum concentration of adsorbed metal

$\mathrm{b}$ - equilibrium constant

Langmuir equation can be written as:

$$
\frac{C}{a}=\frac{C}{a_{m}}+\frac{1}{a_{m} b}
$$

and therefore a plot of C/a vs. C will give a straight line of slope $1 / \mathrm{a}_{\mathrm{m}}$ and intercept $1 / \mathrm{ba}$.

Knowing values for the slope and the intercept allows one to easily calculate values of equilibrium sorption parameters $\mathrm{a}_{\mathrm{m}}$ and $\mathrm{b}$.

The straight line through the data is usually obtained by a linear least - square fitting procedure.

Using this procedure the equations 4 and 5 have been obtained, for phenobarbital sodium and, respectively, amobarbital sodium adsorption on Na-montmorillonite:

$$
\begin{aligned}
& \frac{C}{a}=0.0496 C+0.0797 \\
& \frac{C}{a}=0.0912 C+0.1001
\end{aligned}
$$

The equilibrium parameters for drugs sorption on Na-montmorillonite are shown in Table 6.

Table 6. Adsorption parameters $\mathrm{a}_{\mathrm{m}}$ and $\mathrm{b}$ for phenobarbital

Sodium and amobarbital sodium on na-montmorillonite

\begin{tabular}{|c|c|c|c|}
\hline Drug & $\mathrm{am}_{\mathrm{m}}\left[\mathrm{mg} \mathrm{g}^{-1}\right]$ & $\mathrm{b}\left[\mathrm{mL} \mathrm{mg}^{-1}\right]$ & $r^{2}$ \\
\hline $\begin{array}{c}\text { Phenobarbital } \\
\text { sodium }\end{array}$ & $13 \pm$ & 2.125 & 0.999 \\
\hline $\begin{array}{c}\text { Amobarbital } \\
\text { sodium }\end{array}$ & $10 \pm$ & 1.096 & 0.999 \\
\hline
\end{tabular}

In Figures 9 and 10 SEM analyses after phenobarbital and amobarbital sorption are presented.

It can be seen that phenobarbital sodium and amobarbital sodium are adsorbed on the Namontmorillonite. At lower $p \mathrm{H}$, the drugs molecules are adsorbed on the mineral clay edge sites, via an attraction of the positively charged surface sites.

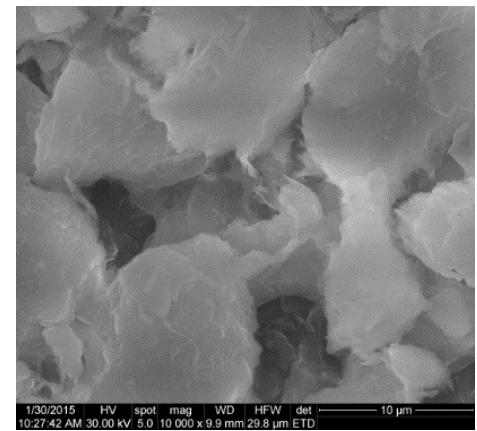

Figure 9. SEM micrographs of natural Na-montmorillonite after phenobarbital sodium sorption

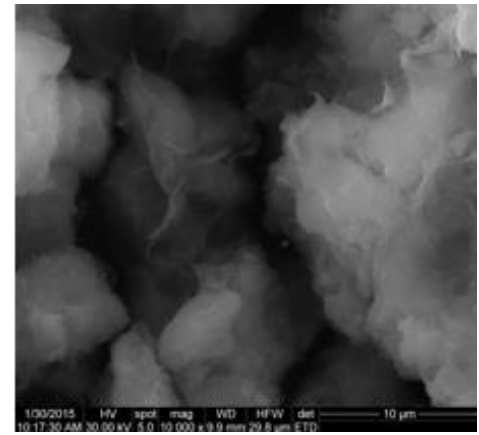

Figure 10. SEM micrographs of natural Na-montmorillonite after amobarbital sodium sorption 


\section{Conclusions}

This study shows that Na-montmorillonite can be used for removal of phenobarbital sodium and amobarbital sodium. Basic findings revealed that Na-montmorillonite has a high adsorption capacity for the weakly acidic phenobarbital sodium and amobarbital sodium.

The Langmuir isotherm model was able to describe the sorption of drugs on the mineral clay. Two hours is sufficient time to reach drug adsorption equilibrium.

Adsorption of both drugs is higher below the $\mathrm{pHZPC}$ of sodium montmorillonite due the neutrality of the drug which adsorbs via an attraction of the positively charged surface sites at lower $\mathrm{pH}$ by weak van der Waals forces.

In order to obtain the most benefit possible from using natural $\mathrm{Na}$ - montmorillonite is to administer it within one hour of the ingestion of a potentially toxic amount of a poison. The amount of drug that is absorbed to the activated charcoal is dependent on the on $\mathrm{Na}$ - montmorillonite /drug ratio,

Adsorption results from Van der Waals forces and desorption of the solute (drug or poison) can occur if Na-montmorillonite is sufficiently present. The poison or the drug ingested adheres to the surface of the Na-montmorillonite and since the mineral clay cannot be absorbed through the digestive tract's membranes, it passes out of the body eliminating the poisons with it.

\section{References}

1. Mc BRIDE, M.B., Environmental Chemistry of Soils, Oxford University Press, Oxford, 1994, p.209.

2. SCHLEGEL, M. L., MANCEAU A., CHATEIGNER D., CHARLET, L., J., Colloid Interface Sci., 215, 1999, p.140.

3. BAILEY, S. W. Crystal structures of clay minerals and their X-ray identification, Mineralogical Society, Brindley and Brown, London, 1980, p. 1-124.

4. MULLER, F., BENSON, G., MANCEAU, A., DITS, V.A., Phys. Chem. Minerals, 24, 1997, p.159.

5. Mc BRIDE, M.B., Clays Clay Min., 30, 1982, p.200.

6. GALAN, E., LISO, M.J., FORTEZA, M., Bol. Soc. Esp. Min., 8, 1985, p.369.

7. CARRETERO, M.I., Appl. Clay Sci,. 21, 2002, p.155.

8. LEFORT, D., DELONCLE, R., DUBOIS, P., Géosciences, 5, 2007, p.6.

9. VISERAS, C., AGUZZI, C., CEREZO, P., LOPEZ-GALINDO, A., Appl. Clay Sci., 36, 2007, p. 37.

10. CARRETERO, M. I., POZO, M., Appl. Clay Sci., 46, 2009, p.73.

11. CAMI, J., FARRE, M., N. Engl. J. Med., 349, 2003, p.975.

12.GOKHALE, R., HUTTENLOCHER, P.R., BRADY, L. B.S. KIRSCHNER, J. Pediatr. Gastroenterol. Nutr., 25, 1997, p.64.

13. MOHAMMED-EBID, A.H., ABDEL-RAHMAN, H.M., Ther. Drug Monit., 23, 2001, p.209.

14 STEFAN, M., BORS, A., STEFAN, D.S., SAVU-RADU, I.A., MARINESCU, C., Rev. Chim., 68, (12), 2017, 2804.

15. STEFAN, M., STEFAN, D.S., Rev. Chim., 60, (11), 2009, 1169.

16. STEFAN, M., STEFAN, D.S., POPESCU, R., Sci. Technol. Environ. Prot., 11, 2004, p.71.

17. GREGG, S., SING, K., Adsorption, Surface Area and Porosity, 2nd ed., Academic Press, London, 1982, p.112.

18. HAGHSERESHT, H., LU, G.Q., Energy Fuels, 12, 1998, p.1100.

19. KUMAR, K.V., CALAHORRO, C.V., JUAREZ, J.M., SABIO, M.M., ALBERO, J.S., REINOSO, F.R., Chem. Eng. J., 162, 2010, p.424.

20. NEWCOMBE, G, Drikas M., Carbon, 35, 1997, p.1239.

21. FARIA, P., ORFAO, J., PEREIRA, M., Water Res., 38, 2004 p. 2043.

22 THE UNITED STATES PHARMACOPEIAL CONVENTION, US Pharmacopeia, 23rd ed., Rockville, Md.: United States Pharmacopeial Convention, Board of Trustees, 1995, p.2053

23. CHIHI, R., BLIDI, I., TRABELSI-AYADI, M., AYARI, F., CR CHIM, 22, 2019 p.188.

24. MAJI, S.K., PAL, A., PAL, T, ADAK, A., J. Surface Sci. Technol., 23, 2007, p.161.

25. OLANIYI, A.A., Central nervous system (CNS) depressants: In Essential Medicinal Chemistry, 3rd ed., Hope Publications, Ibadan, 2005, p. 483.

$\overline{\text { Manuscript received: 8.07.2019 }}$ 